\title{
Recent patent applications in biological imaging
}

\begin{tabular}{|c|c|c|c|c|c|}
\hline Patent number & Description & Assignee & Inventor & $\begin{array}{l}\text { Priority } \\
\text { application } \\
\text { date }\end{array}$ & $\begin{array}{l}\text { Publication } \\
\text { date }\end{array}$ \\
\hline US 20090065697 & $\begin{array}{l}\text { A biological sample imaging method for a sub-millimeter } \\
\text { wave frequency heterodyne imaging system, involving } \\
\text { processing reference intermediate frequency signals } \\
\text { and storing or displaying information in the form of an } \\
\text { image. }\end{array}$ & $\begin{array}{l}\text { California Institute of } \\
\text { Technology (Pasadena, } \\
\text { CA, USA), Coherent } \\
\text { (Santa Clara, CA, USA) }\end{array}$ & $\begin{array}{l}\text { Dengler R, Mueller ER, } \\
\text { Siegel PH }\end{array}$ & $10 / 1 / 2003$ & 3/12/2009 \\
\hline WO 2008155339 & $\begin{array}{l}\text { A biological vector and its radio-fluorinated derivatives } \\
\text { useful in radiopharmaceutical formulation for use in } \\
\text { medicine, particularly in in vivo imaging and for generat- } \\
\text { ing an image of the human or animal body. }\end{array}$ & $\begin{array}{l}\text { GE Healthcare } \\
\text { (Little Chalfont, UK) }\end{array}$ & Bhalla R, Jackson A & $6 / 20 / 2007$ & $\begin{array}{c}12 / 24 / 2008 \\
\text { 2/26/2009 }\end{array}$ \\
\hline $\begin{array}{l}\text { US } 20090047219 \text {, } \\
\text { JP } 2009044964\end{array}$ & $\begin{array}{l}\text { A sugar chain-containing luciferase derivative, where } \\
\text { an organic fluorescent dye is bonded to the luciferase } \\
\text { through the sugar chain; useful for biological imaging } \\
\text { and for producing a luminescent probe that has fewer } \\
\text { biological effects. }\end{array}$ & $\begin{array}{l}\text { National Institute of } \\
\text { Advanced Industrial } \\
\text { Science and Technology } \\
\text { (Tokyo) }\end{array}$ & Ohmiya Y, Wu C & $8 / 14 / 2007$ & $\begin{array}{l}\text { 2/19/2009, } \\
\text { 3/5/2009 }\end{array}$ \\
\hline WO 2009022289 & $\begin{array}{l}\text { An imaging method involving the illumination of a } \\
\text { biological sample with a reference array of spots and } \\
\text { acquiring one sample image consisting of a sample- } \\
\text { related array of spots resulting from the reference array } \\
\text { of spots interacting with the sample. }\end{array}$ & $\begin{array}{l}\text { Konink Philips } \\
\text { Electronics } \\
\text { (Eindhoven, } \\
\text { The Netherlands) }\end{array}$ & $\begin{array}{l}\text { Bakker L, Hulsken B, } \\
\text { Stallinga S, Vossen D }\end{array}$ & $8 / 16 / 2007$ & 2/19/2009 \\
\hline US 20090041316 & $\begin{array}{l}\text { An imaging system used for three-dimensional imag- } \\
\text { ing of biological samples, having a microscope used to } \\
\text { image multiple sections of the sample in adjacent sub- } \\
\text { regions using a vibrating tissue sectioning system and } \\
\text { positioning system. }\end{array}$ & $\begin{array}{l}\text { California Institute } \\
\text { of Technology } \\
\text { (Pasadena, CA, USA) }\end{array}$ & Fraser SE, Koos DS & $8 / 7 / 2007$ & 2/12/2009 \\
\hline WO 2009002529 & $\begin{array}{l}\text { A new compound comprising a urea derivative used } \\
\text { as an inhibitor, linker and metal chelator; useful for } \\
\text { imaging cancer (e.g., ocular, rectal, prostate or breast } \\
\text { cancer). }\end{array}$ & $\begin{array}{l}\text { Johns Hopkins } \\
\text { University (Baltimore) }\end{array}$ & $\begin{array}{l}\text { Foss C, Mease RC, } \\
\text { Pomper MG, Ray S }\end{array}$ & $6 / 26 / 2007$ & $\begin{array}{c}12 / 31 / 2008 \\
\text { 2/12/2009 }\end{array}$ \\
\hline WO 2009016354 & $\begin{array}{l}\text { A nanoparticle comprising a molecular cluster com- } \\
\text { pound and a core semiconductor material provided on } \\
\text { the molecular cluster compound; for use in optical and } \\
\text { electronic devices, solar cells, catalysis, biological imag- } \\
\text { ing or light-emitting diodes. }\end{array}$ & $\begin{array}{l}\text { Nanoco Technologies } \\
\text { (Manchester, UK) }\end{array}$ & $\begin{array}{l}\text { Daniels SM, Mushtaq I, } \\
\text { Pickett N }\end{array}$ & $7 / 31 / 2007$ & 2/5/2009 \\
\hline $\begin{array}{l}\text { WO } 2009006443 \text {, } \\
\text { US } 20090029405\end{array}$ & $\begin{array}{l}\text { New bis-indolyl compounds useful for labeling biologi- } \\
\text { cal molecules, (e.g., proteins, peptides or hormones) for } \\
\text { imaging of biological samples. }\end{array}$ & $\begin{array}{l}\text { Vanderbilt University } \\
\text { (Nashville, TN, USA) }\end{array}$ & $\begin{array}{l}\text { Gore J, Pham W, } \\
\text { Gore JC }\end{array}$ & 6/29/2007 & $\begin{array}{l}1 / 8 / 2009 \\
1 / 29 / 2009\end{array}$ \\
\hline WO 2009009630 & $\begin{array}{l}\text { A luminescent material detection method for multi- } \\
\text { photon biological imaging, involving detecting emission } \\
\text { from the luminescent material at a wavelength that } \\
\text { is shorter than the wavelength of an excitation beam } \\
\text { focused on the luminescent material. }\end{array}$ & $\begin{array}{l}\text { Clemson University } \\
\text { (Clemson, SC, USA) }\end{array}$ & Sun $Y$ & $7 / 11 / 2007$ & $1 / 15 / 2009$ \\
\hline JP 2009002774 & $\begin{array}{l}\text { A biological material detection apparatus with a detector } \\
\text { that detects fluorescence passing through a pinhole pro- } \\
\text { vided in the image focus location of the imaging lens. }\end{array}$ & $\begin{array}{l}\text { Matsushita Electric } \\
\text { Industrial } \\
\text { (Osaka, Japan) }\end{array}$ & Onishi S, Tomikawa T & $6 / 21 / 2007$ & $1 / 8 / 2009$ \\
\hline US 20090012406 & $\begin{array}{l}\text { A method for imaging an aspect of a biological tissue } \\
\text { (e.g., skeletal and cardiac muscle) involving transmit- } \\
\text { ting a light pulse toward the structure at a sufficiently } \\
\text { fast line-resolution rate and providing data in response } \\
\text { to the collected signal for high-resolution imaging. The } \\
\text { method reduces the motion artifacts, tissue motion and } \\
\text { noise, and enhances the image quality. }\end{array}$ & $\begin{array}{l}\text { Barretto RJ, Delp SL, } \\
\text { Llewellyn ME, } \\
\text { Schnitzer MJ }\end{array}$ & $\begin{array}{l}\text { Barretto RJ, Delp SL, } \\
\text { Llewellyn ME, } \\
\text { Schnitzer MJ }\end{array}$ & $7 / 3 / 2007$ & $1 / 8 / 2009$ \\
\hline
\end{tabular}

Source: Thomson Scientific Search Service. The status of each application is slightly different from country to country. For further details, contact Thomson Scientific, 1800 Diagonal Road, Suite 250, Alexandria, Virginia 22314, USA. Tel: 1 (800) 337-9368 (http://www.thomson.com/scientific). 